\title{
The effect of glucose on enzyme activities and phenol utilization in Trichosporon cutaneum grown in continuous culture
}

\author{
Åke SpÅNNING and Halina Y. NeUJAHR* \\ Department of Biochemistry and Biotechnology, The Royal Institute of Technology, S-100 44 Stockholm, Sweden
}

(Received 12 October 1989; revised 6 April 1990; accepted 2 May 1990)

\begin{abstract}
The soil yeast Trichosporon cutaneum was grown in continuous culture on a minimal medium containing phenol or glucose, or both. The utilization rate of the carbon substrate and the specific activities of catechol 1,2-dioxygenase (EC 1.13.11.1), pyruvate kinase (EC 2.7.1.40), alanine aminotransferase (EC 2.6.1.2) and aspartate aminotransferase (EC 2.6.1 .1) were determined. Both substrates were utilized simultaneously, the rate of glucose utilization being much higher than that of phenol. Basal activity of catechol 1,2-dioxygenase [3-5 mU ( $\mathrm{mg}$ protein $)^{-1}$ ] was found in glucose-grown cells. High glucose concentrations $\left(20 \mathrm{~g} \mathrm{l}^{-1}\right)$ did not prevent the induction of phenol metabolism as reflected in the derepression of catechol 1,2-dioxygenase and the consumption of phenol. However, glucose partially repressed the overall phenol metabolism when $T$. cutaneum was grown on phenol together with glucose: phenol utilization and catechol 1,2-dioxygenase activity were reduced by $60 \%$ and $75 \%$ respectively. Complete derepression of catechol 1,2-dioxygenase did not occur until the glucose was depleted. Catechol 1,2-dioxygenase was repressed, but not inactivated, by glucose, as judged from the wash-out profile during transition from growth on phenol to growth on glucose. Pyruvate kinase activity was about twice as high in glucose-grown cells as in phenol-grown cells, and the level of the enzyme during growth on glucose was unaffected by the presence of phenol. Aspartate aminotransferase activity was higher in cells grown with phenol, or phenol together with glucose, than in cells grown on glucose alone. Alanine aminotransferase activity increased only when both substrates were present.
\end{abstract}

\section{Introduction}

The strictly aerobic yeast Trichosporon cutaneum can utilize a wide variety of carbon sources and has an outstanding capacity to metabolize various aromatic compounds, including unsubstituted phenol (Neujahr \& Varga, 1970; Gaal \& Neujahr, 1979; Sparnins et al., 1979; Anderson \& Dagley, 1980, 1981; Sze \& Dagley, 1984; Powlowski \& Dagley, 1985). T. cutaneum can also grow on at least six disaccharides (Mörtberg \& Neujahr, 1986), and on polymeric carbohydrates, e.g. xylans (Hrmova et al., 1984) and starch (De Mot et al., 1984). This metabolic versatility raises the question as to whether the various degradative pathways are affected by glucose.

In thick suspensions of washed cells from cultures grown on glucose, the onset of phenol metabolism (phenol uptake and the appearance of degradative enzymes) is considerably delayed when glucose ( $30 \mathrm{mM})$ is added to the suspension together with phenol, glucose being continuously utilized. In corresponding cells grown on phenol, and containing all the phenol-metabolizing enzymes, the rate of phenol utilization is also low in the presence of glucose (Gaal \& Neujahr, 1981). However, another strain of $T$. cutaneum has been reported to utilize phenol in preference to glucose, both in batch and in carbon-limited continuous culture (Shoda \& Udaka, 1980). We have earlier demonstrated an overinduction of several metabolic enzymes after transition from limiting to non-limiting phenol as the carbon source (Spånning \& Neujahr, 1987). The present report describes the response of $T$. cutaneum in continuous culture to changes in the carbon source, with respect to the utilization of phenol and glucose, alone or in combination, and the repression/derepression of relevant enzymes.

\section{Methods}

Organism and growth conditions. Trichosporon cutaneum (Neujahr \& Varga, 1970; Varga \& Neujahr, 1970a) ATCC 46490 was used in all experiments. This yeast is strictly oxidative and metabolizes phenol by the ortho-fission pathway. It was grown at $28^{\circ} \mathrm{C}$ in continuous culture in a New Brunswick Bioflo-C30 fermenter on a mineral salts medium which contained $\left(\mathrm{g} \mathrm{l}^{-1}\right)\left(\mathrm{NH}_{4}\right)_{2} \mathrm{SO}_{4}(4 \cdot 0), \mathrm{Na}_{2} \mathrm{HPO}_{4} .2 \mathrm{H}_{2} \mathrm{O}(0 \cdot 75)$, 


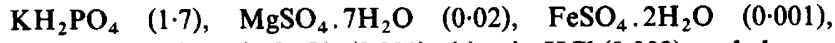
$\mathrm{MnSO}_{4} \cdot \mathrm{H}_{2} \mathrm{O}(0.001), \mathrm{CaCl}_{2}(0.001)$, thiamin- $\mathrm{HCl}(0.002)$, and glucose (19.9) and/or phenol (0.35). The working volume of the fermenter was kept at $1.4 \mathrm{I}$ by a fixed overflow line, the aeration rate was 1 vol. air (vol. liquid) ${ }^{-1} \mathrm{~min}^{-1}$, and the $\mathrm{pH}$ was maintained at 6.8 by automatic titration with $1 \mathrm{M}-\mathrm{KOH}$. Sterile medium was delivered by a peristaltic pump. Foam formation was prevented by adding Adecanol. Cultures were harvested when growth was observed on the fermenter wall or when pseudo-mycelium formation was detected microscopically. This occurred only after culture times exceeding $200 \mathrm{~h}$.

Enzyme assays. Enzyme activities were determined in situ, in permeabilized cells, by a modification of the method of Miozzari $e t$ al. (1978). Samples from the fermenter were centrifuged and washed twice in cold deionized water. The pellet was then resuspended to a cell density of $3.5 \mathrm{~g}^{-1}$ in $50 \mathrm{mM}$-HEPES, pH 7.0, containing $0.05 \%$ Triton $\mathrm{X}-100$ and frozen once for at least $40 \mathrm{~h}$ before assaying enzyme activity. All enzymes tested proved to be equally stable to freeze/thaw treatment, and activities were determined within $0.5 \mathrm{~h}$ of the thawing of cells. Pyruvate kinase (EC 2.7.1 .40), alanine aminotransferase (EC 2.6.1.2) and aspartate aminotransferase (EC 2.6.1.1) were assayed according to Bergmeyer (1983), except for the following buffer modifications; triethanolamine $/ \mathrm{HCl}$ was substituted for $\mathrm{Tris} / \mathrm{H}_{2} \mathrm{SO}_{4}$ in the pyruvate kinase assay and HEPES was used instead of phosphate buffer in the assay of the aminotransferases. Catechol 1,2-dioxygenase (EC 1.13.11.1) was determined as previously described (Varga \& Neujahr, 1970b). Enzyme activities were measured in duplicate at ambient temperature $\left(21 \pm 1^{\circ} \mathrm{C}\right)$ using a Gilford 2600 spectrophotometer. Duplicate values differed from mean values by less than $5 \%$. Observed reaction rates were linear for at least $3 \mathrm{~min}$, indicating that they were not diffusion limited. One unit of activity $(U)$ is defined as the amount of enzyme transforming $1 \mu \mathrm{mol}$ of substrate in $1 \mathrm{~min}$ under the assay conditions. Specific activities are expressed as milliunits (mU) per $\mathrm{mg}$ total cell protein. Catechol 1,2-dioxygenase assay mixtures contained about $25 \mathrm{mg}$ protein while the other three contained about $60 \mathrm{mg}$. Protein content of the permeabilized cells was determined as described by Herbert et al. (1971).

General analyses and chemicals. All chemicals were of reagent grade and purchased from commercial sources (Spånning \& Neujahr, 1987). Triton X-100 was from Rohm \& Haas, phosphoenolpyruvate, lactic dehydrogenase and catechol were from Sigma, and Adecanol (a polyoxypropylene polyoxyethylene copolymer) was from Asahi (Japan). Phenol was determined in culture supernatants by the colorimetric method using 4-aminoantipyrine as modified by Der Yang \& Humphrey (1975). Glucose was determined by the anthrone/sulphuric acid method (Spiro, 1966). Cell densities were estimated by measuring the optical density at $650 \mathrm{~nm}$ and are expressed as dry weight of cells per litre.

\section{Results and Discussion}

The effect of high glucose concentrations on the metabolism of phenol by $T$. cutaneum was studied in continuous culture under three sets of conditions. The specific growth rate in each case was $0 \cdot 12 \mathrm{~h}^{-1}$ (Figs 1-3). The glucose concentration employed $\left(20 \mathrm{gl}^{-1}\right)$ is known to exert catabolite repression on the metabolism of glucose in, for example, Saccharomyces cerevisiae (Perlman \& Mahler, 1974, and references therein). Catechol 1,2-dioxygenase, the second enzyme of phenol metabolism, was chosen as a marker for the phenoldegrading pathway. This enzyme is induced simultan-

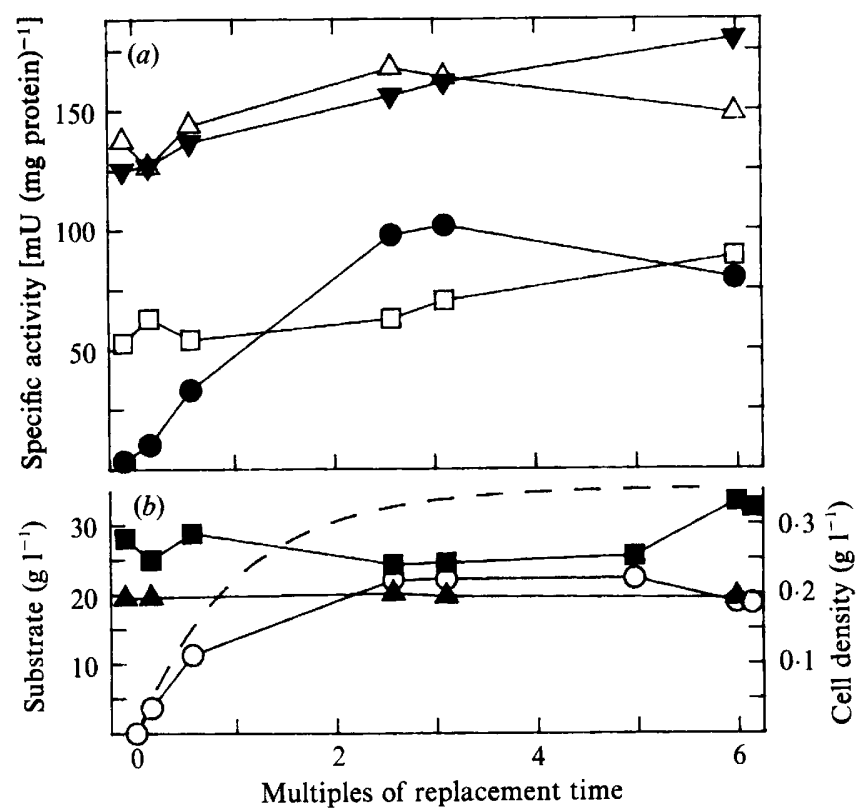

Fig. 1. Transition from steady-state growth on glucose to growth on glucose and phenol, showing (a) enzyme activities and (b) substrate levels and cell density. After steady state was established on glucose $\left(19.9 \mathrm{~g} \mathrm{t}^{-1}\right)$, phenol $\left(0.35 \mathrm{~g}^{-1}\right)$ was added to the medium reservoir. The time of this change is taken as the zero replacement time. One replacement time corresponds to $8.4 \mathrm{~h}$. Catechol 1,2-dioxygenase; $\triangle$, pyruvate kinase; $\square$, alanine aminotransferase; $\nabla$, aspartate aminotransferase; $O$, phenol multiplied by 100 for legibility in the figure; $\boldsymbol{\Delta}$, glucose; $\boldsymbol{Q}$, cell density. The dashed line indicates calculated accumulation of phenol in the case of no consumption.

eously with the first enzyme (phenol 2-monooxygenase, EC 1.14.13.7) and the third enzyme (muconate cycloisomerase, EC 5.5.1.-) of phenol metabolism (Gaal \& Neujahr, 1981). Pyruvate kinase, one of the regulatory enzymes of the glycolytic pathway, was chosen as an indicator of glucose metabolism. The aminotransferases were assayed to elucidate whether transamination reactions are affected by phenol metabolism.

\section{Effect of glucose on phenol metabolism}

Fig. 1 illustrates the derepression of phenol metabolism in the presence of glucose. Cells grown with $20 \mathrm{~g}$ glucose $1^{-1}$ had a basal catechol 1,2-dioxygenase activity of 3-5 $\mathrm{mU}$ (mg protein) ${ }^{-1}$. Phenol consumption and the derepression of catechol 1,2-dioxygenase started immediately after the introduction of phenol into the fermenter. However, the specific activity of catechol 1,2dioxygenase only increased to about $25 \%$ of the activity in cells grown on phenol alone (cf. Fig. 2), indicating that glucose partially represses catechol 1,2-dioxygenase. This is supported by the increased rate of catechol 1,2dioxygenase derepression in the absence of glucose (Figs 1 and 2). The effect of glucose on phenol metabolism 

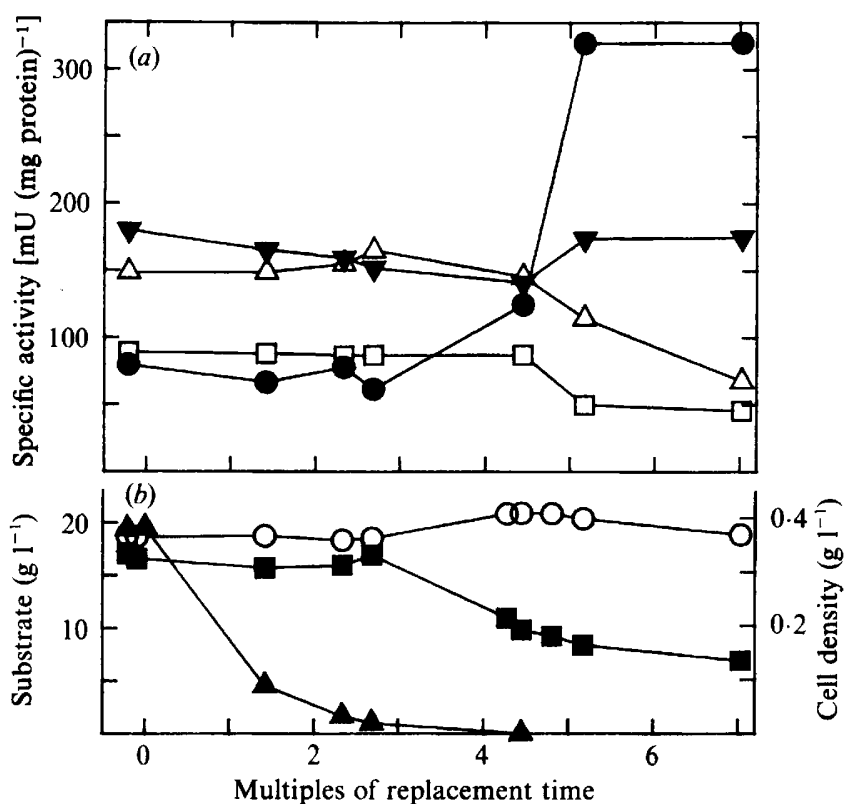

Fig. 2. Transition from steady-state growth on glucose and phenol to growth on phenol, showing $(a)$ enzyme activities and $(b)$ substrate levels and cell density. After steady state had been established on glucose $\left(19.9 \mathrm{~g} \mathrm{l}^{-1}\right)$ and phenol $\left(0.35 \mathrm{~g}^{-1}\right)$, the growth substrate was changed to phenol $\left(0.35 \mathrm{~g} \mathrm{l}^{-1}\right)$. Symbols as in Fig. 1 .

during a change of carbon source from phenol to glucose is shown in Fig. 3. Catechol 1,2-dioxygenase activity decreased almost immediately after the shift (Fig. $3 a$ ) and resembled the predicted wash-out curve for phenol (Fig. 3b). This suggests repression, but not inactivation, of catechol 1,2-dioxygenase by glucose. The results confirm the earlier observation that the levels of phenoldegrading enzymes in phenol-grown (washed) cells remain constant in the presence of glucose, although phenol consumption is then largely inhibited (Gaal \& Neujahr, 1981). In Candida maltosa L4, glucose $\left(20 \mathrm{~g} \mathrm{1}^{-1}\right)$ repressed catechol 1,2-dioxygenase synthesis almost completely, without causing any major decrease in enzyme activity (Hofmann \& Krüger, 1985).

The partial repression by glucose of catechol 1,2dioxygenase in $T$. cutaneum is also reflected in the $60 \%$ decrease of phenol utilization rate, which was 0.17 and $0.07 \mathrm{~g}$ ( $\mathrm{g}$ dry wt) ${ }^{-1} \mathrm{~h}^{-1}$ in the absence and presence of glucose, respectively. The cell yield decreased from $0.84 \mathrm{~g}$ dry wt (g substrate) $)^{-1}$ on phenol alone to $0.58 \mathrm{~g} \mathrm{~g}^{-1}$ on phenol and glucose. This indicates a more efficient phenol utilization in the absence of glucose.

We conclude that, in continuous culture, phenol is taken up and metabolized by $T$. cutaneum shortly after its introduction into the medium, even when glucose concentrations are high. This contrasts with earlier observations with washed cell suspensions (Gaal \& Neujahr, 1981) in which the derepression of phenol metabolism was delayed by $3-4 \mathrm{~h}$ when the initial glucose
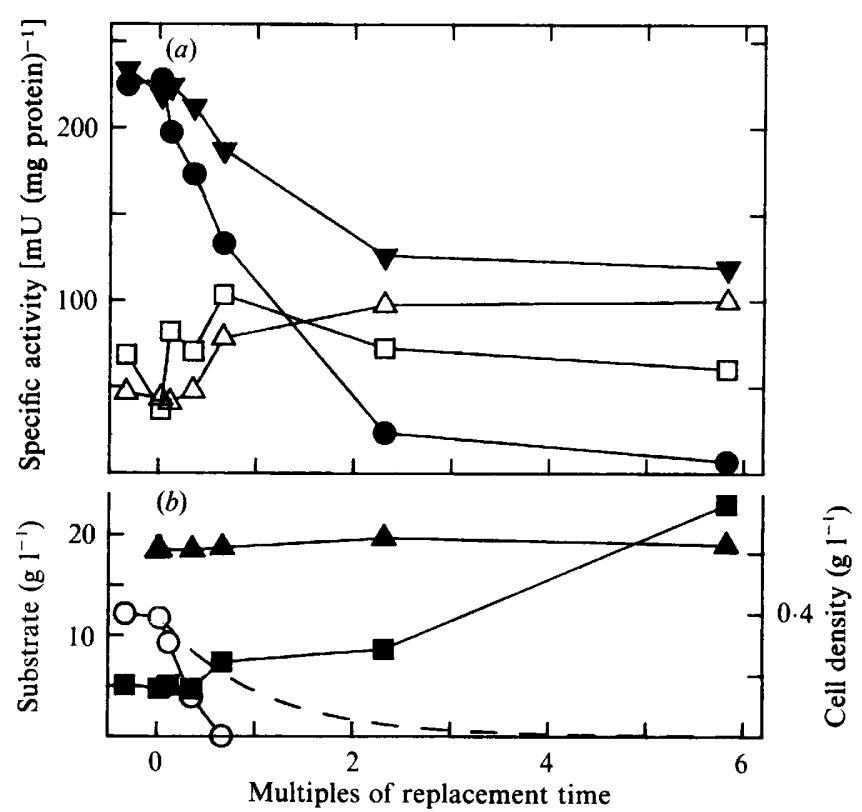

Fig. 3. Transition from steady-state growth on phenol to growth on glucose, showing $(a)$ enzyme activities and $(b)$ substrate levels and cell density. After steady state had been established on phenol (0.35 $\left.\mathrm{g} \mathrm{l}^{-1}\right)$, the growth substrate was changed to glucose $\left(19.4 \mathrm{~g} \mathrm{l}^{-1}\right)$ and $18.5 \mathrm{~g}$ glucose $\mathrm{I}^{-1}$ was added directly to the fermenter. The dashed line indicates calculated wash-out of phenol in the case of no consumption. Symbols as in Fig. 1.

concentration was $5 \mathrm{~g} \mathrm{l}^{-1}$. Such washed cells consumed only small amounts of phenol in the presence of glucose. The difference may partly depend on the lack of easily utilizable nitrogen sources in washed cell suspensions, in combination with the general catabolite repression resulting from high glucose concentrations. Shoda \& Udaka (1980) reported that, during batch culture of another strain of $T$. cutaneum, phenol metabolism started shortly after the addition of phenol to a culture grown on $1.6 \mathrm{~g}$ glucose $1^{-1}$, and that phenol was utilized in preference to glucose. However, Hofmann \& Krüger (1985) observed that in batch cultures of Candida maltosa L4, glucose completely repressed phenol metabolism. These differences may reflect variations in the efficiency of catabolite repression produced by different levels of glucose in different yeast strains under different experimental conditions (cf. a discussion by Melling, 1977).

\section{Effect of phenol on glucose metabolism}

Phenol has some effect on the overall metabolism of glucose in $T$. cutaneum, as reflected in the decrease in glucose utilization rate from 0.27 to $0.24 \mathrm{~g}$ (g dry wt) ${ }^{-1}$ $\mathrm{h}^{-1}$ in the absence and presence of phenol respectively. After growth on phenol together with glucose, the cell yield decreased from $0.70 \mathrm{~g} \mathrm{~g}^{-1}$ to $0.58 \mathrm{~g} \mathrm{~g}^{-1}$. However, 
the small increase in pyruvate kinase activity during growth on glucose and phenol indicated that the rate of glycolysis was similar to that of cells grown on glucose alone (Fig. 1). The pattern of pyruvate kinase activity, its decrease after depletion of glucose (Fig. 2) and its derepression in the presence of phenol (Fig. 3), resembles the regulation of this enzyme in other oxidative yeasts. Two mechanisms for the regulation of pyruvate kinase have been proposed. One is the control of enzyme concentration; the other is the regulation of enzyme activity by allosteric effectors (ATP and fructose-1,6diphosphate). Several oxidative yeasts, e.g. Candida lipolytica, are thought to contain a pyruvate kinase which is regulated by the former mechanism, the level of activity being higher on glycolytic than on gluconeogenic carbon sources (Gancedo et al., 1967; Hirai et al., 1975; Caubet et al., 1988). However, the possible involvement of allosteric effectors in the regulation of pyruvate kinase activity was not studied in our experiments.

\section{Transamination reactions during metabolism of phenol}

Aspartate aminotransferase activity was higher in cells grown on phenol or phenol together with glucose than in cells grown on glucose alone (Figs 1 and 2). The enzyme was subject to repression, but not inactivation, by glucose, as judged from the wash-out profile during a change of carbon source from phenol to glucose (Fig. 3). In contrast to aspartate aminotransferase, alanine aminotransferase activity was similar in cells grown on either glucose or phenol. However, upon the introduction of phenol, alanine aminotransferase activity increased. We conclude that some transamination reactions are affected by growth on phenol, but their specific role has not been studied.

\section{General remarks}

Part of the repression of phenol metabolism observed in the presence of glucose may be effected at the cell membrane. Höfer \& Dahle (1972) showed that in Rhodotorula gracilis, the cell membrane was one of the important regulatory sites of cell metabolism. The derepression of phenol-degrading enzymes depends on phenol concentration (Spånning \& Neujahr, 1987). Phenol is transported by (at least) two uptake systems, one of which is an inducible, high-affinity system (Mörtberg et al., 1988). If glucose or a catabolite thereof interferes with this system, this would result in an immediate decrease in the intracellular phenol concentration, i.e. in the level of the available inducer. This could explain the repression pattern of catechol 1,2dioxygenase and aspartate aminotransferase after a change from phenol to glucose (Fig. 3).
This work was supported by The National Swedish Board for Technical Development (STUF).

\section{References}

ANDERSON, J. J. \& DAGLEY, S. (1980). Catabolism of aromatic acids in Trichosporon cutaneum. Journal of Bacteriology 141, 534-543.

ANDERSon, J. J. \& DAGLEY, S. (1981). Catabolism of tryptophan, anthranilate, and 2,3-dihydroxybenzoate in Trichosporon cutaneum. Journal of Bacteriology 146, 291-297.

Bergmeyer, H. U., Grassl, M. \& Walter, H.-E. (1983). Reagents for enzymatic analysis: enzyme. In Methods of Enzymatic Analysis, 3rd edn, vol. 2, pp. 136-138, 160-161, 303-304. Edited by H. U. Bergmeyer, J. Bergmeyer \& M. Grassl. Weinheim: Verlag Chemie.

Caubet, R., Guerin, B. \& Guerin, M. (1988). Comparative studies on the glycolytic and hexose monophosphate pathways in Candida parapsilosis and Saccharomyces cerevisiae. Archives of Microbiology 149, 324-329.

De Mot, R., Demeersman, M. \& Verachtert, H. (1984). Comparative study of starch degradation and amylase production by nonascomycetous yeast species. Systematic and Applied Microbiology 5, 421-432.

Der Yang, R. \& Humphrey, A. E. (1975). Dynamic and steady state studies of phenol biodegradation in pure and mixed cultures. Biotechnology and Bioengineering 17, 1211-1235.

GaAl, A. \& Neujahr, H. Y. (1979). Metabolism of phenol and resorcinol in Trichosporon cutaneum. Journal of Bacteriology 137, 1321.

GAAL, A. \& NEUJAHR, H. Y. (1981). Induction of phenol-metabolizing enzymes in Trichosporon cutaneum. Archives of Microbiology 130, 5458.

Gancedo, J. M., Gancedo, C. \& Sols, A. (1967). Regulation of the concentration or activity of pyruvate kinase in yeasts and its relationship to gluconeogenesis. Biochemical Journal 102, 23c-25c.

Herbert, O., PhIPps, P. I. \& Strange, R. E. (1971). Chemical analysis of microbial cells: the biuret method. Methods in Microbiology 5B, 244-249.

Hirai, M., Tanaka, A. \& Fukui, S. (1975). Difference in pyruvate kinase regulation among three groups of yeasts. Biochimica et Biophysica Acta 391, 282-291.

HOFMANN, K. H. \& KRÜGER, A.-K. (1985). Induction and inactivation of phenol hydroxylase and catechol oxygenase in Candida maltosa L4 in dependence on the carbon source. Journal of Basic Microbiology 25, 373-379.

HöFER, M. \& DAHLE, P. (1972). Glucose repression of inducible enzyme synthesis in the yeast Rhodotorula gracilis. European Journal of Biochemistry 29, 326-332.

Hrmova, M., Biely, P. Vrsanska, M. \& Petrakova, E. (1984). Induction of cellulose- and xylan-degrading enzyme complex in the yeast Trichosporon cutaneum. Archives of Microbiology 138, 371-376.

Melling, J. (1977). Regulation of enzyme synthesis in continuous culture. In Topics in Enzyme and Fermentation Technology, pp. 10-42. Edited by A. Wisemann. Chichester: Ellis Horwood.

MiozZari, G. F., Niederberger, P. \& HÜtTER, R. (1978). Permeabilization of microorganisms by Triton X-100. Analytical Biochemistry 90, 220-233.

MÖRTBERG, M. \& NEUJAHR, H. Y. (1986). Transport and hydrolysis of disaccharides by Trichosporon cutaneum. Journal of Bacteriology 168 , 734-738.

Mörtberg, M., SPÅNNING, A. \& NeUjaHR, H. Y. (1988). Induction of high-affinity phenol uptake in glycerol-grown Trichosporon cutaneum. Journal of Bacteriology 170, 2383-2384.

NeUJAHR, H. Y. \& VARGA, J. M. (1970). Degradation of phenols by intact cells and cell-free preparations of Trichosporon cutaneum. European Journal of Biochemistry 13, 37-44.

Perlman, P. S. \& MaHLeR, H. R. (1974). Derepression of mitochondria and their enzymes in yeast: regulatory aspects. Archives of Biochemistry and Biophysics 162, 248-271. 
Powlowski, J. B. \& Dagley, S. (1985). $\beta$-Ketoadipate pathway in Trichosporon cutaneum modified for methyl-substituted metabolites. Journal of Bacteriology 163, 1126-1135.

SHODA, M. \& UDAKA, S. (1980). Preferential utilization of phenol rather than glucose by Trichosporon cutaneum possessing a partially constitutive catechol 1,2-oxygenase. Applied and Environmental Microbiology 39, 1129-1133.

SPÅNNING, $\AA$. \& NeUjaHR, H. Y. (1987). Growth and enzyme synthesis during continuous culture of Trichosporon cutaneum on phenol. Biotechnology and Bioengineering 29, 464-468.

Sparnins, V. L., BurbeE, D. G. \& DaGley, S. (1979). Catabolism of Ltyrosine in Trichosporon cutaneum. Journal of Bacteriology 138, 425430 .
SPIRo, R. G. (1966). Analyses of sugars found in glycoproteins. Methods in Enzymology 8, 3-26.

SzE, I. S.-Y. \& DaGley, S. (1984). Properties of salicylate hydroxylase and hydroxyquinol 1,2-dioxygenase purified from Trichosporon cutaneum. Journal of Bacteriology 159, 353-359.

VARGA, J. M. \& NEUJAHR, H. Y. (1970a). Isolation from soil of phenolutilizing organisms and metabolic studies on the pathways of phenol degradation. Plant and Soil 33, 565-571.

VARGA, J. M. \& NeUJahr, H. Y. (1970b). Purification and properties of catechol 1,2-oxygenase from Trichosporon cutaneum. European Journal of Biochemistry 12, 427-434. 